\title{
Penerapan Metode Brainstorming Untuk Meningkatkan Kemampuan Mengemukakan Pendapat Siswa di Kelas XII IPS 1 SMA Negeri 1 Tanjung Jabung Timur
}

\author{
Edy Isman ${ }^{1}$ \\ ${ }^{1}$ Guru SMA Negeri 1 Tanjung Jabung Timur \\ Correspondance email: Edyisman01@ gmail.com
}

\begin{abstract}
Abstrak. Berdasarkan pengamatan yang dilakukan oleh peneliti ,ada empat masalah yang terjadi dalam kelas tersebut yaitu : kurang antusiasnya para siswa dalam mengikutipembelajaran sejarah, kurang responya siswa ketika memberikan tangapan dan dangahan, siswa kurang aktif untuk bertanya dan menjawab pertanyaan guru dan pembelajaran juga masih menggunakan pendekatan teacher center. Metode yang dilakukan adalah metode menelitian tindakan kelas yang dilaksanakan di SMA Negeri 1 Tanjung Jabung Timur kelas XII IPS 1 .Pada siklus pertama siawa belum melaksanakan metode brainstorming dengan baik tetapi, setelah peneliti belajar dari siklus pertama, diantaranya guru memberikan motivasi dengan memberlan reward, dan membuat media yang menarik perhatian siwa, hasilnya pada sisklus kedua ketiga, dan keempat katagori kemampuan mengemukakan pendapatsiswa pada tingkatan baik. Karena siswa antusias dalam mengatisipasi pertanyaan, mencari ide atau gagasan,menemukan ide dan gagasan ,merumuskan pendapat dan mengajukanpendapat dalam pembelajaran sejarah.
\end{abstract}

Kata Kunci :Branstorming;Mengemukan;Pendapat;Reward

Abstract. Based on observations made by researchers, there are four problems that occur in the classroom, namely: the students are less enthusiastic in participating in historical lessons, students are less responsive when giving responses and answers, students are less active in asking and answering teacher questions and learning also still uses the approach teacher center. The method used is the method of researching classroom actions carried out at SMA Negeri 1 Tanjung Jabung Timur class XII IPS 1. In the first cycle students have not implemented the brainstorming method properly but, after the researcher learned from the first cycle, among them the teacher provided motivation by giving rewards, and making media that attract students 'attention, the results are in the second third cycle, and in the four categories the ability to express students' opinions at a good level. Because students are enthusiastic in anticipating questions, looking for ideas or ideas, finding ideas and ideas, formulating opinions and proposing opinions in history learning.

Keywords: Brainstorming; Expressing; Opinion; Reward

\section{PENDAHULUAN}

Berawal dari pengamatan awal yang dilakukan oleh peneliti di SMA n egeri 1 Tanjung Jabung Timur di kelas XII IPS 1 ada empat masalah yang terjadi dalam kelas yakni siswa kurang aktif untuk bertanya dan menjawab pertanyaan guru dan pembelajan juga masih menggunakan teacher center.Untuk jelasnya masalah masalah diatas akan dipaparkan yaitu 1) kurangnya antusias dari para siswa dalam mendengarkan dan menyimak tersebut yaitu : kurang antusiasnya para siswa dalam mengikuti pembelajaran sejarah, kurang responnya siswa ketika memberikan tanggapan dan sangahan, penjelasan dari guru terkait materi yang disampaikan. 2) pada siswa diberikan kesempatan untuk bertanya, membrerikan tanggapan dan sangahan terhadap suatu peristiwa atau materi hanya ada dua sampai tiga orang yang berpendapat dan mengajukan pertanyaan, sedangkan siswa yang lainya hanya diam dan memperhatikan. 3) pada saan siwa diminta untuk menjawab pertanyaan yang dilontarkan oleh guru sebagian besar dari siswa hanya diam dan sebagian lagi hanya membuka buku paket yang ada didepan mejanya. Sehingga, guru harus menjawab pertanyaan 
sendiari.padahal siswa telah mempunyai buku sumber.tetapi siswa kurang memanfaatkan sumbernya dengan baik. Setlah peneliti mewawacarai sebagian siswa kelas tersebut siswa itu enggan untuk menjawab karena ada dua factor : pertama siswa takut pertanyaannya ditertawakan oleh temanya, kedua, siawa takut pertanyaan salah. 4) pembelajaran juga masih menggunakan teacher center yang hanya terpusat pada guru sehingga tidak memberikan kesempatan pada siswa berperan akatif yang mengakibatkan siswa cepat bosan dalam belajar karena pada saat pembelajaran merasa menoton dengan meposisikannya hanya penerima ilmu saja dalam pembelajaran di kelas XII IPS 2 ini sebenarnya guru menjelaskan materi sudah jelas.

Dari masalah tersebut dapat terlihat adanya masalah dalam kelas XII IPS 2 seharusnya pembelajaran sejarah pembelajaran yang menyenangkan, pembelajaran yang menuntut siswa aktif, selain itu guru seharusnya lebih beragan menggunakan metode pembelajaran agar siswa dalam kelas tidak bosan, Salah satu metode yang menggunakan tehnik student center dan mendorong siawa untuk mengemukan asgumentasinya secara aktif yaitu metode pembelajaran brainstorming, Menurut Karwati ( dalam Rosmiati, 2013; 18 ) metode brainstorming yaitu memberikan kesempatan kepada siswa untuk mampu menampilkan kemandirian serta pengarahan diri, mimiliki keterbukaan dan keutuhan diri dalam memilih alternative tindakan yang terbaik, mampu menyampaikan pendapat mengatualisasikan diri dalam pemecahan suatu masalah serta mampu menghargai pendapat orang lain.Metode brainstorming ini memberikan keleluiasaan siswa untuk mengemulkan argumenya dan memacahkan suatu masalah serta mampu menghargai pendapat orang lain bertujuan untuk mengumpulkan gagasan atau pendapat dalam rangka menentuktan dan memilih berbagai pernyataan sebagai jaeaban terhadap pertanyaan yang berkaitan dengan pembelajaran.

Penggunaan metode brainstorming dalam pembelajaran sejarah ini lebih diarahkan untuk mengajarkan daya kritis siswa dalam mengemukan pendapat dan untuk mengembangkan pengetahuandan wawasan,dalam metode ini siswa dituntut lebih aktif dalam belajar mengemukan pendapat. Untuk menjadikan proses belajar mengajar yang demikian, guru dituntut memikirkanmelasakan langkah lagkah yang memberi kemudahan bagi siswa agar dapat belajar secara aktif guna mencapai tujuan pemgajaran secara efektif.

Tujuan dari penelitian ini adalah 1) Menambah wawasan serta ketrampilan dalam penerapan metode pambelajaran pada kegiatan belajar mengajar selajutnya. 2) Meningkatkan kemampuan serta ketrampilan siswa mengunakan metode brainstoring. 3) Memperbaiki permasalahan pembelajaran yang dihadapi dan menambah wawasan serta ketrampilan pembelajaran yang dapat meningkatkan hasil belajar siswa untuk meningkatkan mutu pembelajaran.

\section{LANDASAN TEORI}

\section{Metode Brainstorming}

Menurut Roestiyah (2008:73) metode brainstorming yaitu tehnik mengajar yang dilakukan guru dengan cara melontarkan suatu masalah ke kelas oleh guru, kemudian siswa menjawab,menyatakan pendapat, atau memberi komentar sehingga memungkinkan masalah tersebutbberkembang menjadi masalah baru. Secara singkat dapat diartikan sebagai suatu cara untuk mendapatkan banyak berbagai ide dari sekelompok manusia dalam yang singkat. Sedangkan menurut Rawlinson (1977:27 ) brinstorming adalah cara untuk memdapatkan banyak ide dari sekolompok manusia dengan cara yang singkat dari dua pendapat tersebut dapat disimpulkan bahwa negan metode branstorming ini siwa dilatih untuk mencari,menemukan dan mengemukan gagasan dalam proses pembelajaran.

Metode ini melatih keaktifan siswa dalam bertanya dan mengolah pertanyaan sehingga mendorong sisiwa untuk berpartisispasipasi dalam proses pembelajaran. Adapun langkah langkah dari penerapan metode branstorming ini menurut Rawlinson (1977:35) yakni:

1) Menjelaskan persoalan, guru mrngangkat dan menjelaskan permasalahan yang diangkat kemudian menjelaskan cara siswa berpartisipasi dalam pembelaran tersebut.

2) Merumuskan kembali persoalan guru menjelaskan kemnbali persoalan dan siswa merumuskan pertanyaan pertanyaan yang diajukan

3) Mengembangkan ide unik, maksudnya mengembangkan ide ide yang inovatif dan diluar fariasi dan kebiasaan yang mungkin bias di kembangkan.

4) Mengevaluasi ide yang dihasilkan guru dan siswa mengevaluasi ide yang telah terkumpul dan menyipulkanya. 


\section{Mengemukakan Pendapat}

Menurut Effendi (dalam suprihatna,2013:14) pendapat merupakan respon yang diberikan sesorang yaitu komunikasi kepada komunitor yang sebelumnya telah memberikan pertanyaan. Menurut Anindarwati(2013:4) menjelaskan bahwa mengemukan pendapat adalah kemampuan menyampaikan gagasan atau pikiran yang secara lisa yang logis tanpa paksaan atau kehendak sendiri serta menggunakan bahasa yang baik. Ketrampilan mengemukakan pendapat dalam pembelajaran sejarah ini yaitu :

1) Mengidentifikasi pertanyaan

Pada tahapan ini sisiwa diarahkan untuk mengidentifikasi pertanyaan .Tahapan dari mengidentifikasi pertanyaan tersebut meliputi : siswa mengamati pertanyaan yang di berikan oleh guru, siswa mencari maksud/tujuan dsri pertanyaan yang diajukan .Kemudian setelah sisiwa menemukan maksud dan tujuan dari pertanyaan yang di ajukan tersebut sisiwa diharapkan mampu mengemukakan pendapat dengan menjawab pertanyaan tersebut

2) Mencari Ide atau gagasan

Pada tahapan ini sisiwa mencari ide atau gagsan untuk dijadikan pendapat.Tahap pencarian ide atau gagasan tersebut diperoleh dari berbagai sumber referensi seperti buku ,artikel ataupun media lain yang dapat dijadikan sumber rujukan.

3) Menemukan ide atau gagasan

Pada tahapan ini sisiwa diarahkan agar mampu menemukan ide atau gagasan dari berbagai sumber tersebut yang nantinya akan di gunakan dalam berpendapat .

4) Menyampaikan pendapat

Pada tahapan ini siswa mengemukakan pendapatnya berdasarkan ide atau gagasan yang diperoleh dari berbagai sumber.

\section{METODE PENELITIAN}

Peneliti akan menggunakan metode penelitian Tindakan Kelas (PTK) atau Classroom Action research (CAR).Desain penelitian yang di pakai oleh penulis adalah desain penelitian model Kemmis dan Mc Taggart Karena desain model ini sangat sederhana dan cocok apabila diterapkan pada penelitian ini,yang ditunjukan untuk menghindari rasa bosan siswa terhadap metode brainstorming. Ada empat tahapan dalam desain penelitian yaitu :1.Perencanaan, 2.Pelaksanaan, 3.Pengamatan dan 4. Refreksi .

Penelitian tindakan kelas ini dilaksanakan di SMAN 1 Tanjung Jabung Timur, subjek penelitian adalah para sisiwa kelas XII IPS 1 SMAN 1 Tanjung Jabung Timur tahun ajaran 2019/2020 berjumlah 27 siswa. Pada penelitian tindakan kelas ini peneliti akan berkaborasi dengan guru sejarah SMAN 1 Tanjung Jabung Timur yaitu Noviardi, S.Pd. Instrumen Penelitian yang di gunakan adalah peneliti. Manusia sebagai Instumen utama dibantu oleh alat-alat. Berikut ini adalah alat bantu yang peneliti gunakan penelitian ini:

1) Pedoman Observasi

Dengan adanya panduan absrvasi ini maka peneliti mengamati dan mencatat apa yang terjadi ketika pembelajaran berlangsung. Data yang ingin diperoleh dalam penelitian ini yaitu gagasan yang di peroleh oleh sisiwa dsn keaktifan dalam mengemukakan pendapat

2) Pedoman wawancara

Pedoman wawancara ini merupakan kisi-Kisi pertanyaan yang disiapkan oleh peneliti sebelum melakukan wawancara. Jawaban dari yang diwawancarai dengan wawancara semi terstruktur ini dijadikan refreksi bagi peneliti untuk perbaikan tindakan selanjutnya

3) Lembar Penilaian diri

Lembar penilaian diri digunakan untuk mengetahui partisipasi sisiwa dalam proses pembelajaran berikutnya siswa diminta untuk menilai sikapnya dalam proses ini .

4) Dokumentasi

Dokumentasi yang digunakan adalah perangkat dokumen resmi yang digunakan selama proses belajar mengejar berlangsung seperti silabus dan rencana pelaksanaan pembelajaran. Selain itu, dokumen penunjung seperti tugas-tugas siswa catatan tantang kehadiran dan aktivitas sisiwa dikelas juga digunakan sebagai dokumentasi

5) Catatan Lapangan

Pada catatan Lapangan ,peneliti dan mitra dapat memperoleh gambaran perihal proses pembelajaran dalam catatan lapangan juga dapat dilihat sudah sejauh mana permasalahan dalam pembelajaran teratasi.hasil catatan lapangan didiskusikan dengn mitra dalam catatan lapangan mitra mencatat segala aspek Selma proses pembelajaran berlangsung dan catatan tersebut sebagai sumber yang akan peneliti gunakan dalam penelitian tindakan kelas . 
Data yang diperoleh dari siswa ,guru,mitra dan pihak lain yang relevan dengan penelitian ini. Pada tahap ini peneliti memperoleh data tindakan -tindakan yang dilakukan peneliti pada saat pembelajaran. Kegiatan yang diamati pada penelitian ini adalah kinerja sisiwa dalam mencari ide, mengumpulkan ide dan mengemukakan pendapatmya. Adapun tektnik pengumpulan data yaitu dengan beberapa cara:

1) Observasi

Padsa observasi penilaian ini, dilakukan observasi penilaian untuk menilai seberapa banyak ide yang dikumpulkan oleh siswa dan keaktiffan sisiwa ketika mengemukakan pendapat. Untuk melihat guru dalam proses pembelajaran dan penerapan metode branstorming digunakan lembar observasi aktivitas guru dan menilai kontribusi siswa padsa proses pembelajaran berlangsung. Untuk melihat peristiwa yang terjadi dikelas peneliti menggunakan catatan lapanagan. Kolaborasi antara mitra dengan peneliti sangat penting dalam keberhasilan penelitian , maka perlu adanya kerjasama dan saling berdiskusi dari mulai perencanaan ,penerapan dan hasil pembelajaran ,dari hasil pengamatan ini akan diperoleh kesimpulan dan menentukan langkah penelitian berikutnya

2) Wawancara

Wawancara dalam penelitian ini digunksn mengetahui tanggapan guru terutamam mengenai penerapan guru terutama mengenai penerepan metode brainstorming terhadap kemamouan mengemukakan pendapat data secara kualitatif yang diperoleh untuk bahan analisi pada tahap selanjutnya terumata untuk mengetahui aktifitas siswa selama penerapan metode brainstorming.

3) Studi Dokumentasi

Pada penelitian ini yaitu rencana pelksanakan pembelajaran ,lembar penilaian keaktifan mengemukakan pendapat dan ide ide yang didapatkan oleh siswa

Dalam penelitian tindakan kelas (PTK) analisis dsts sudah dilakukan penelitian .sedangkan semua aspek penelitian .sedangkan cara-cara untuk menguji tingkat validasi dalam PTK akan dipaparkan sebagai berikut:

1) Member Check

Pada penelitian ini peneliti memeriksa kembali informasi atau data data yang telah diperoleh selama proses penelitian berlangsung

2) Saturation

Pada proses ini, peneliti mengumpulkan data dari setiap tindakan dan ketika data itu sudsh berada di titik jenuh maka penelitian itu di anggap telah seleesai .

3) Expert Openion

Pada penelitian ini expert opinion yang memiliki sejalan dengan pendapat di atas bahwa peneliti akan meminta kepada orang di anggap ahli dalam hal ini adalah pembibing dalam penelitian ini untuk memeriksa semua tahapan -tahapan kegiatan penelitian dan memberikan arahan atau judgements terhadap masalahmasalah penelitian yang dikaji.

4) Audit Tral

Peneliti juga memeriksa catatan-catatan yang ditulis oleh peneliti atau pengamat mitra peneliti an lainnya. Hal ini juga berguna, apabila peneliti akan memperolrh informasi kembali atau data yang ada, atau waktu mempersiapkan laporan.Audit trail dapat dilakukan oleh kawan sejawat peneliti, yang memiliki pengetahuan dan keterampilan melkukan penelitian tindakan kelas yang sama

\section{HASIL DAN PEMBAHASAN}

Perencanaan Penerapan Metode Brainstorming Pelaksanaan dalan pembelajaran sejarah Perencanaan yang peneliti laksanakan dalam menerapkan metode brainstorming untuk meningkatkan kemampuan mengemukakan pendapat siswa di kelas XII IPS 1 SMAN 1 Tanjung Jabung Timur, akan peneliti deskripsikan sebagai berikut:

Pada observasi awal akan dijelskan kembali mengenai hasil dari pengamatan peneliti yang termasuk dalam kegiatan pra penelitian dikelas XII IPS 1 SMAN 1 Tanjung Jabung Timur. Peneliti melakukan pra penelitian selama 3 kali ,berbagai masalah yang terlihat di sekoalah ini terutama XII IPS 1 meliputi pertama, kurangnya antusias dari pada siswa dalam mendebgsrkan dan menyimak penjelasan dari guru terkait materi yang di sampaikan.kedua ,kurangnya inisiatif siswa untuk mengemukakan pendapatnya ,Ketika guru membrikan kesempatan kepada sisiwa untuk mengjukan pertanyaaan ,ketiga, pembelajaran masih menggunakan pendekatan teavher center yang hanya berpusat pada guru sehingga tidak berpusat pada gueru sehingga tidsk memberikan kesempatan siswa berperan aktif.

Berdasarkan hasil refleksi peneliti terkait hasil dari kegitatan obsrvsi prs penelitian ,dan diskusi peneliti dengan guru mitra Dra.N.Tati K usmiyati ,maka dalam penelitin ini diabtaranya mengenai rencana pelksanaan pembelajaran yang mengacu kepada kurikulum 2006,metode pembelajaran,persiapan materi penilaian dan penugasan 
,peneliti berencana akan meneraokan metode branstroming .Brainstorming di sisni dipilih karena memenuhi kriteria ysng di perlukan guna memecahkab berbagai permasakahan yang di temukan di kelas XIIPS 4 selama kegiatabn observasi awal dilaksanakan.

Hal selanjutnya yang dibsahas yaitu mengenai pembuatsn silabus setelah membuat silabus peneliti membuat RRP yang mana sekolah ini masih menggunanakan kurikulum KTSP .perencanaan tentang berapa banyaksiklus yang akan dilaksanakan dalam penalitian ini juga di tentukan bersama guru mitra .Penelit menjelaskan penelitian tindakan kelas ,tidsk dapat di pastikan kapan siklus hrus berhenti , dan kapan siklus mencapai titik jenuh .mka dari itu ,peneliti tidak dapat memastikan akan sampai berapa siklus ,tergantung seberapa siswa memahami metode brainstorming. Mengenai pembagian kelas penelitian ,setelah melakukan disikusi maka diputuskan penelitiam diadakan dikelas XI IPS4 .Jadwal masuk kelas aka dilaksanakan pada hari senin pada jam 09.00-09.40 WIB dikarenakan ada jeda iistirahat maka dilanjutkan pada jam 10.00-10.40 .sedangkan materi yang harus disampaikan DI sesuaikan dengan materii yang belum di sampaikan di kelas XI IPS 4.

\section{Deskripsi Data Hasil lembar observsi Kemampuan mengemukakan pendapat}

Pengolahan data secara keseluruhan selama pelaksanaan siklus tindakan dilakukan dari hasil observasi sisiwa ini dilakukan untuk mengetehui seberapa besar tingkat kemapouan mengemukakan pendapat tahap pertama yang di lakukan oleh peneliti dalam mengolah data yaitu menjumlakan indicator secara keseliruhan yang telah di dapatkan oleh siswa dan menghitung presentasi dari setiap siklsnya Berikut hasil penjumlahan sekor setiap siklusnya.

\section{Gambar 1.}

\section{Kemampuan Mengemukakan Pendapat Pada Setiap Siklusnya}

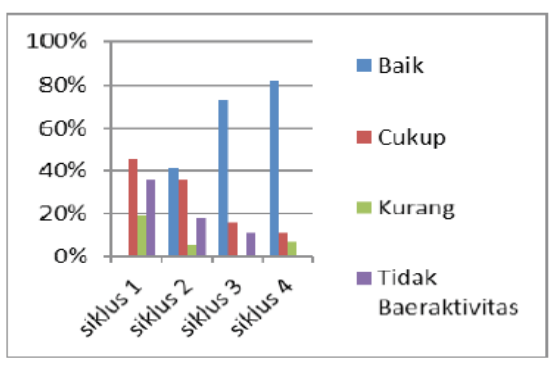

Tabel 1.

Presentasi Kemampuan Mengemukakan Pendapat Sisiwa Pada Setiap Siklusnya

\begin{tabular}{|l|c|c|c|c|}
\hline \multirow{2}{*}{$\begin{array}{c}\text { Hasil } \\
\text { Presentasi }\end{array}$} & \multicolumn{4}{|c|}{ Aspek yang dinilai } \\
\cline { 2 - 5 } & Baik & Cukup & Kurang & $\begin{array}{c}\text { Tidak } \\
\text { Ber- } \\
\text { aktivitas }\end{array}$ \\
\hline Siklus I & - & $45 \%$ & $19 \%$ & $36 \%$ \\
Siklus II & $41 \%$ & $36 \%$ & $3 \%$ & $18 \%$ \\
Siklus III & $73 \%$ & $16 \%$ & - & $11 \%$ \\
Siklus IV & $82 \%$ & $11 \%$ & $7 \%$ & - \\
\hline
\end{tabular}

Berdasarkan data di atas menjelaskn bahwa kemampuan sisiwa pada setiap siklusnya mengalami perkembangan dengan baik sesuai dengan jumlah siklusnya maka ada empat siklus maka ada empat kategori yang bias di terjemahkan. Dari table di atas menurut data di atas bahwa hasil presentase kemampuan mengemukakan pendapat yang paling tinggi pada siklus satu berada pada kategori "cukup" yaitu 45\% .Pada kategori ini sisiwa hanya mengemukakan pndapatnya pada apa yang di tulis di buku paket,dan masih sedikit yang mengemukakan pendapatnya karena pada tahap ini guru dan sisiwa masih dalam tahap adaptasi dalam pembelajaran sejarah dengan metode brainstorming.

Kategori yang kedua yaitu "Baik" data obsrvasi sisiwa pada siklus yang kedua .berdasarkan data tersebut bahwa presentase yang paling tinggi terdapat pada kategori bik yaitu sebesar $41 \%$ yang sudah mengalami kenaikan yang signifikan. Pada siklus ini guru dan sisiwa sudah bias menyesuaikan dengan metode brainstorming dalam 
pembelajaran sejarah tersebut.Disisini guru sudah berusaha lebih memperhatikan RPP atau scenario dalam pembelajaran ,guru juga menyiapkan pertanyaan - pertanyaan yang menarik untuk cari jawabannya oleh siswa dan media yang digunakan lebih menarik dibandingkan siklus sebelumnya .Sehingga siswa lebih antusias dibandingkan dengan sisklus sebelumnya. Kategori yang ketiga 'Baik', data observasi sisiwa pada siklus ketiga .Berdasarkan data tersebut bahwa presentase yang paling tinggi yaiu pada kategori baik sebesar $73 \%$ siswa mengemukakan gagasannya dan mengalami dalam perkembangan dalam kemampuan mengemukakan pendapatnya.Siswa pada siklus ini mengalami peningkatan. Karena disisni guru mempersiapkan scenario pembelajaran lebih matang seperti materi dan pertanyaan-pertanyaan yang menarik. Selain itu juga guru mempersiapkan dengan baik media yang digunakan sehingga siswa lebih antusias lagi dalam proses pembelajaran.

Kategori yang kempat "Baik" data observasi siswa pada siklus keempatatau terakhir berdasarkan data tersebut bahwa presentase paling tinggi Pada kategori 82\%.Pada siklus keempat ini peneliti dan observersasi ingin mengetahui sejauh mana perubahan yang terjadi jika dilakukan siklus sekali lagi, hasil observasi pada siklus keempat ini mengalami sedikit peningkatan yang tidak terlalu signifikan dari siklus sebelumnya maka peneliti dan guru mitra memutuskan bahwa pelaksanakaan tindakan salah penelitian ini hanya sampai empat kali,

\section{Deskripsi Data Hasil Observasi Aktifitas Guru Pada Saat Penerapan Metode Brainstorming}

Pengolahan data secara keseluruhan selama pelaksanaaan siklus tindakan dilakukan dari hasil observasi aktivitas gruru .Hal tersebut bertujuan untuk sejauh mana usaha peneliti dalam mengembangkan kemampuan mengemukakan pendapat sisiwa XII IPS 1. Data hasil observasi guru ini diambil dari deskripsi di setiap siklusnya:

Berdasarkan hasil pengamatan dri setiap siklusnya hasil observasi guru dalam menerapkan metode brainstorming mengalami peningkatan,hal tersebut dapat ditunjukan dalam sisklus I observasi guru secara keseluruhan berada pada kategori 'Baik" ,terlihat dari dua puluh satu komponen Sembilan komponen sudah berada pada kategori baik.pada siklus kedua observasi gruru secara keseluruhan berada pada kategori 'Baik', adanya peningkatan dari siklus sebelumnya komponen baiknpada siklus dua yaitu sebesar tiga belas komponen sudah berada pada kategori baik.jika dilihat dari perubahan sikus I hingga siklis II terdapat perubahan yang cukup baik hal ini di sebabkan peneliti belum belajar dari kekurangan-kekurangan mengajajarnya disiklus I dalam menerapkan metode brainstorming.

Pada siklus III ini secara keseluruhan berada pada kategori "' sangat baik" ,pada siklus ini adanya peningkatan yang signifikan .Kategori pada siklus ini yaitu delapan belas komponen. Pada siklus IV data yang di peroleh tidak mengalami peningkatan yang signifikan pada siklus ini secara keseluruhan berada pada kategori "sangat baik" kategori baik berjumlah Sembilan belas komponen .Dari data-data yang di peroleh di atas hasil keseluruhan dari setiap siklus nya berada pada kategori 'sangat baik'.

\section{Deskripsi Data Hasil Lembar Observasi Penilaian diri siswa}

Pengolahan data secara keseluruhan selama pelaknanaan siklus tindakan dilakukan dari hasil lembar observasi sisiwa inindilakukan untuk mengukur seberapa besar tingkat kontribusu sisiwa dalam proses pembelajaran dengan menggunakan metode brainstorming. Berikut hasil konstribusisiswa pada sertiap siklusnya .

Tabel 2.

Hasil Kontribusi Siswa Pada Setiap Siklusnya

\begin{tabular}{|c|c|c|}
\hline Pelaksanaan Siklus & Skor & Rata-rata \\
\hline I & 746 & 68 \\
\hline II & 921 & 83 \\
\hline III & 991 & 90 \\
\hline IV & 998 & 92 \\
\hline
\end{tabular}

Adapun kategori yang peneliti kembangkan untuk lembar penelian siswa adalah sebagai berikut:

1) 100-90: Sangat berkontribusi

2) 89-80: Berkontribusi

3) 79-70: Cukup berkontribusi

4) 69-60: Tidak berkontribusi 
Berdasarkan penyajian tabel, dapat diperoleh hasil bahwa kontribusi siswa pada setiap siklus mengalami peningkatan ,dari tabel diketahui skor keseluruhan didetiap siklus.Pda siklus satu ,kontribusi siwa memperoleh 746, untuk siklus dua kontribusi siswa meningkat menjadi 921, kontribusi pada siklus tiga juga mengalami peningkatan yaitu 991,namun kontribusi siwa pada siklus empat mengalami peningkatan yang signifikan yaitui sebesar 998.

Kendala-kendala yang dihadapi oleh Guru Sejarah Dalam Mengembangkn Metode Brainstorming Untuk Meningkatkan kemampuan mengemukakan pendapat. Kendala yang di hadapi guru ketika menerapakan metode brainstorming dapat dipaparkan sebagai berikut :

a) Siswa harus selalu di motifasi ketika ingin mengemukakan pendapatnya .

b) Siswa terlalu nergantung pada guru .Masih terpaku pada paradigma guru sebagai pusat pembelajaran atau guru yang harus dominan <teacher center>.

c) Guru harus lebih matang dalam membuat scenario pembelajaran.

d) Guru harus lebih enarik dalam membuat pertanyaan agar siuswa lebih antusias .

e) Media yang di gunakan harus semenarik mungkin agar siwa lebih tertarik dalam proses pembelajaran.

f) Siwa masih terpaku pada satu sumber yaitu buku paket.

Maka setelah terdapat beberapa kendala yang terdapat dalam penerapan metode brainstorming untuk meningkatkan kemampuan mengemukakan pendapat.Peneliti berupaya dan berusaha untuk mengatasi kendalakendala yang di hadapi.Solusi masalah sebgai berikut:

a) Guru selalu memotivasi sisiwa agar siswanya berkompetisi dalam mengemukakan pendapatnya.

b) Siswa harus di biasakan dengan pembelajaran yang aktif <student center>.

c) Perlu rencana pembelajaran yang matang agar proses pembelajaran berjalan dengan baik

d) Guru harus selalu member motivasi kepada siswa agar mereka antusias dalam membaca materi pembelajaran.

e) Guru harus membuat media semenarik mungkin agar siswa lebih antussias dalam proses pembelajaran.

f) Guru harus menyediakan sumber-sumber yang relevan untuk menunjang dalam proses pembelajaran

\section{Analisis Kemampuan Mengemukakan Pendapat melalui Metode Brainstorming Dalam Pembelajaran Sejarah.}

Penelitian tindakan kelas ini telah dilakukan oleh peneliti dan observer secara keseluruhan dalam proses pembelajaran secara di kelas .Berdasarkan hasil penelitian yang dilakukan oleh peneliti dengan mengguinakan instrument berupa observasi siswa ,observasi guru , catatan lapangan dan studi dokumentasi. Maka didapatkan hasil bahwa penerapan metode brainstorming dapat meningkatkan kemampuan mengemukakan pendapat dalam pembelajran sejarah ,hal tersenut telah disdeskripsikan dalam pembahasan siklus di atas.pada siklus pertama masih pada kategori cukup baik karena siswa masih perlu adaptasi dengan metode brainstorming dan sumber belajar yang hanya terpaku pada buku teks. Namun setelah peneliti belajar dari siklus pertama ,diantaranya guru pemberikan motivasi dengan memberikan reward, dan membuat media yang menarik perhatian siswa . Hasilnya pada siklus kedua ,ketiga dan keempat kategori kemampuan mengemukakan pendapat siswa berada pada tingkatan baik .begitupun p;ada hasil observasi kontribusi siuswa pada siklus kedua ,ketiga dan keempat berada pada tingkatan baik.

Pada siklus kedua, ketiga dan keempat sudah pada kategori baik, karena siswa antusias dalam mengeidentifikasi pertanyaan ,mencari ide ataui gagasan ,menemukan ide ataui gagasan ,merumuskan pendapat dan mengajukan pendapat dalam pembelajaran sejarah.Dalam penerapan metode ini ,siswa lebih sering mengungkapakan gagasannya hal tersebut sejalan dengan yang dikatakan raulin son <1977:27> brainstorming adalah cara untuk mendapatkan banyak ide dari sekelompok manusia dengan cara singkat.dalam hal ini waktu yang di berikan kepada siswa dalam mengungkapkan gagasamnnya hanya pada saat pembelajaran sejarah saja .sedangkan menurut Sudjana <1983:35>brainstorming adalah metode pembelajaran yang dilakukan dalam kelompokyang peserta didiknya memiliki latar belakang dan pengetahuan yang berbeda -beda . maka metode ini melatih keaktifsn siwa dalam bertanya dan mengolah pertanyaan sehingga mendorong siswa untuk berpadrtisipasi dalam proses dalam proses pembelajaran. Menurut pernyataan Rawlin son dan Sudjana di atas dapat di ambil kesimpulan bahwa bpembelajaran dengan menggunakakan metode bainstorming akan terjadi proses pembelajaran yang lebih aktif dengan gagasan gagasan yang muncul dasri siswa .Terbukti dari setiap siklusnya terdapat peningkatan dengan dengan menerapkan metode brainstorming.Pada siklus kedua siswa sudah mengalami peningkatan yang signifikan karena siswa antusias 
dengan pembelajran menggunakan metode branstorming. Siswa mengalami peningkatan kembalin karena siswa sudah semakin terbiasa dengan diterapkannya metode brainstorming dalam pembelajaran sejarah.

Selain itu ,melalui metode brainstorming ini,siswa dilatih untuk mencari,menemukan,mengelolah sumber informasi tersebut menjadi idea tau gagasan yang akan digunakan nya dalam mengemukakan pendapat. Disamping itu siswa juga dituntut mampu untuk bekerja secara individu dapatb di amati dengan pendapat yang di kemukakan oleh nasution (2010:7) menyatakan "pembelajaran merupakan prosess mengolah dan mengembangkan tingkah laku subyekn belajar dalam rangkah pembentukan pribadinya". Proses tukar menukar pendapat, menanggapi suatu pendapat oaring lain dan menanmbahkan suatu pendapat merupakan aktivitas yang baik perekembangan intelektual siswa.

Menurut Parera (1987185) mengemukakan pendapat adalah kemampuan menggunakan bahasa dengan baik, tepat dan seksama. Berakitan dengan tujuan metode brainstorming bahwa semakin sering mengemukakan pendapatnya maka pendapatnya akan semakin baik dan bahsa yang di sampaikan akan semakin baik dan berkualitas. Hal ini terbukti dengan penelitian yang dilakukan peneliti bahwa kemampuan mengemukakan pendapat pada siklus kedusa,ketiga dan keempat kemampuan mengemukakan pendapat berada pada kategori baik.

\section{Implikasi penerapan Kemampuan Mengemukakan Pendapat Melalui Metode Brainstorming Dalam Pembelajaran Sejarah}

Dari siklus pertama sampai siklus keempat respon siswa dalam penilaian diri terkait dengan pendapat siswa pembelaran sejarah di kelas XII IPS 1 menunjukan bahwa metode tersebut dapat meningkatkan kemampuan mengemukan pendapat siswa. Selain itu ,pembelajaran sejarah dengan menggunakan metode brainstorming menjadi lebih menyenangkan ,siswa jadi lebih focus .siswa juga dapat mengemukakan pendapatnya lebih leluasa sehimgga kemampuan suiswa dalam menyampaikan pendapat dapat terlihat.

Penggunaan metode brainstorming pada saat proses pembelajaran ,memperlihatkan keaktifan siswa pada saat megemukakan pendapat, serta respon sisiwa dili8hat dari penilaian diri siswa ,yangb pada umumnya menunnjukan ketertarikan atau antusias pada proses pembelajaran .penerapan metode brainstorming dalam pembelajaran sejarah tidak hanya meningkatkan kemampuan mengemukakan pendapat siswa yang memang menjadi focus peneligtian ,ternyata penerapan metode brainstorming ini dapat memberikan dampakn yang lain,dalam keaktifan sisiwa dan minat terhadap pembelajaran ,siswa menjadi lebih tertarik lebih focus dalam pembelajaran sejarah,

Guru mempersiapkan silabus yang nantinya sebagai acuan untuk membuat rencana pelaksanaan pembelajaran (RPP) yang di sesuaikan dengan kondisi serta karakterstik siswa untuk diterakpan dalam setiap pelaksanaan tindakan, mempersiapkan materi pembelajaran, mempersiapkan media pembelajaran yang dapat menarik perhatian serta akan menimbulkan antusias dlam proses pembelajaran. Dlam setiap siklusnya peneliti meyiapkan pertanyan-pertanyaan yang menrik agar siswa berperan aktif dalam megemukakan pendapat, tidak hanya itu peneliti juga mempersipkan lembar observasi ,guru dan lembar penilaian diri siswa. Dalam penerapan metode brainstorming pada kegiatan pembuka guru menjelaskan tata cara pembelajaran menggunakan metode brainstorming dan memberikan motifasi awal kepada siswa agr siswa termotifasi dalam pembelajaran sejarah. Pada kegiatan inti guru memberikan pertanyaan pertanyaan menarik yang nantinya akan di cari idea tau gagasanya oleh siswa kemudian guru member waktu siswa untuk nmencari idea tau gagasannya dari berbagai sumber selanjutnya guru memberi kesempatan kepad siswa untuk mengemukakan gagasannya.ketika siswa sedang mengemukakan pendapatnya gurur harus menunda penilaian terhadap gagasan yang diutarakan oeleh siswa hal yang di lakukan oleh guru ketika metode brainstorming ini diterapkan yaitu guru harus selalu memberikan motifasi kepada siswa agar siswa sebanyak mungkin mengemukakan pendapatnya .setelah selesai penerapan metode brainstorming guru dan siswa bersama sama mengevaluasi pendapat yang di kemukakan olleh siswa .pada kegiatan penutup guru dan siswa bersama sama menyimpulkan materi secara keseluruhan kemudian guru memberikan tindak lanjut berupa tugas.

Hasil setelah diterapkannya metode brainstorming dalam proses pembelajaran secara ,megnalami peningkatan kemampuan mengemukakan pendapat secara bertahap pada setisp siklusnya setelah diterapkannya metode braindtorming. Hal ini terbukti dari hasil lembar observasi pada saat proses pembelajaran ,keaktifan siswa pada saat mengemukakan pendapat ,serta respon siswa dilihat dari penilaian diri siswa ,yang pada umumnya menunjukan ketertarikan atau antusias pada proses pembelajaran dengan menggunakan metode brainstorming. 
Dari siklus pertama sampai siklus keempat respon siswa dalam penilaian diri terakait dengan pendapat siswa terhadap metode brainstorming dalam pembelajaran sejarah dikelas XII IPS 1 menunjukan bahwa metode tersebut dapat meningkatkan kemampuan mengemukakan pendapat siswa selain itu, pembelajran sejarah dengan menggunakan metode brainstorming menjadi lebih menyenangkan,siswa lebih berperan secara aktif dalam kegiatan pembelajaran dan siswa jadi lebih bafokus. Siswa juga dapat mengemukakan pendapatnya lebih leluasa sehingga kemampuan siswa dalam menyampaikan pendapat dapat terlihat. Selain itu pertanyaan -pertanyan yang menarik untuk menstimulus siswa dalam mencari gagasan yang menemukan gagasan yang sesuai dengan materi pembelajaran dan harus dapat merangsang siswa untuk mengajukan pendapatnya. namun kendala kendala tersebut dapat diatasi melalui upaya upaya perbaikan yaitu dengan cara selalu memotivasi siswa agar siswanya berkompetisi dalam mengemukakan pendaspat nya,siswa harus di biasakan dengan pembelajaran yang aktif (student center), perlu rencana pembelajaran yang mateng agar proses pembelajaran berjalan dengan baik, guru harus selalu member motivasi kepada siswa agar mereka antusias dalam membaca materi pembelajaran ,guru harus membuat media semenarik mungkin aghar siswa lebih antusias dalam proses pembeljaran dan guru harus menyediakan sumber sumber ysng relevan untuk menunnjang dalam proses pembelajaran.

\section{SIMPULAN}

Adapun kesimpulan yang dapat diambil dari penelitian ini adalah 1) perencanaan penerapan metode brainstorming dalam pembelajaran sejarah guru sebagai peneliti berkolaborasi dengan guru mitra sebagai pengajar yang sudah berpengalaman, guru mitra juga dapat member masukan kepada guru sebagai peneliti. 2) pelaksanaan metyode brainstorming atau curah gagasan dalam meningkatkan kemampuan mengemukakan pendapat dilakukan setiap tindakan siklus. Pelaksanaan tindakan dalam penerapan metode brainstorming yaitu ada tiga hal yang harus dilakukan dalam pelaksanaan metode brainstorming yaitu kegiatan pembuka, kegitan inti dan kegiatan penutup. 3) pada pelaksaaan tindakan I kemampuan mengemukakan pendapat siswa masih bdalam kategori cukup dengan presentase $45 \%$,tetapi pada pelkaksanaan tindakan II presentase kategori yaitu 41\%, pada tindakan III presentase kategori baik yaitu 73\%, dan pada tindakan IV presentase baik yaitu 82\%, sehingga pada tindakan V kemampuan mengemukakan pendapat sudah terkihat sangat baik. 4) dalam penerapan metode brainstorming sebagain upaya meningkatkan kemampuan mengemukakan pendapat siswa dalam pembelajaran sejarah memang menemui beberapa kendala. Kendala yang di alami sebagai bagian besar disebabkan karena keterbatasan waktu untuk mengeksplorasi pertanyaan dan materi pembelajaran lebih mendalam.

Adapun saran yang ingin penulis sampaikan berkaitan dengan penerapan metode brainstorming dalam pembeljaran sejarah sebagai berikut: bagi guru, metode brainstorming ,merupakan salah satu alternative solusi bagi pembelajaran sejarah dikelas . guru harus senantiasa membimbing dan memfasilitasi agar siswa lebih dominan aktif dalam proses pembelajaran guru harus memperjelas aturan dari metode ini sehingga siswa lebih paham ketika melakukannnya.

1) Bagi guru,metode bainstorming merukan salah satu alternative solusi bagi pembelajaran sejarah dikelas. Guru harus senantiasa mmembimbing dan memfasilitasi siswa agar lebih dominan aktif dalam proses pembelajaran. Guru harus memperjelas aturan dari metode ini, sehingga siswa lebih paham melakukanya.

2) Bagi sekolah, sekolah harus lebih mendukung, memfasilitasi, dan memperbaikin fasilitas yang sudah ada, sehingga guru-guru lebih muda saat mengajar dikelas. Kemudian guru juga harus mendukung metode pembelajaran yang ada selama itu berdampak positif untuk siswa.

3) Bagi peneliti lebih lanjut, dalam penerapan metode brainstorming inji masih banyak kekurangan oleh karena itu ,banyak perbaikan - perbaikan yang harus dilakukan oleh penelitian selanjutnya agarv penerapan metode brainstorming ini dapat diterapkan dengan semaksimal mungkin.

4) Bagi peneliti, pada penelitian metode brainstorming ini telah meningkatkan kemampuan mengungkapkn pendapat dalam pembelajaran sejarah. Siswa lebih ikut berpatisipasi dalam proses pembelajaran terutama dalam mengemukakan gagasan .Namun dalam hal ini peneliti menyadari masih banyak kekurangan dalam pelaksanaan penelitian ini maka peneli berharap untuk penelitian selanjutnya, materi harus lebih di kuasai oleh guru , membuat semenarik mungkin agar siswa termotivasi . 


\section{DAFTAR PUSTAKA}

Hamalik, O. 2008 . Proses Belajar Mengajar . Jakarta. PT Bumi Aksara .

Hasyimi,A.H .2001. Mendidik Ala Rasullulah. Jakarta :Pustaka Azzam

Nasution . 2010. Didaktik asas-asas mengajar. Jakarta :Bumi Aksara

Parera,J.D. 1987. Belajar mengemukakan Pendapat .Jakarta:Erlangga

Rawlinson,JG. 1977. Berfikir Kreatif dan Brainstorming .Jakartsa :Erlanga

Roestiyah .2008. Strategi Belajar Mengajar. Jakarta:Rineka Cipta

Roamiyati ,V .2013. Penerapan metode Pembelajaran Brainstorming Untuk Meningkatkan Kemampuan Berpikir Kritis Siswa Kelas XII IPS 1 Di Sma Negeri Situraja (Penelitin Tindakan Kelas Pada mata pelajaran Geografi ). Bandung .Skripsi Sarjana pada UPI Bandung : Tidak diterbitkan

Suprihatna,A. 2013. Penerapan metode learning stars with A question dalam pembelajaran sejarah untuk meningkatkan kemampuan mengemukakan pendapat siswa (Penelitian Tindakan kelas di kelas XI IPS SMA Negeri Tanjung sari ). Bandung Skripsi sarjana pada FPIPS UPI Bandung:Tidak diterbitkan 